\title{
Solar pumps: a sustainable alternative for agricultural systems in areas of high marginalization
}

\section{Bombas solares: una alternativa sustentable para los sistemas agropecuarios en zonas de alta marginación}

MONTEMAYOR-TREJO, José Alfredo†, WOO-REZA, José Luis*, YESCAS-CORONADO, Pablo and FRIAS-RAMIREZ, Ernesto

Instituto Tecnológico de Torreón

ID $1^{\text {st }}$ Author: José Alfredo, Montemayor-Trejo / ORC ID: 0000-0002-8287-4072, CVU CONACYT ID: 201396

ID $1^{\text {st }}$ Coauthor: José Luis, Woo-Reza / ORC ID: 0000-0001-8222-286x, CVU CONACYT ID: 68213

ID $2^{\text {nd }}$ Coauthor: Pablo, Yescas-Coronado / ORC ID: 0000-0003-1763-6517, CVU CONACYT ID: 217602

ID $3^{\text {rd }}$ Coauthor: Ernesto, Frias-Ramirez / ORC ID: 0000-0002-6631, CVU CONACYT ID: 67627

DOI: $10.35429 / J A N R E .2019 .5 .3 .1 .7$

Received September 25, 2019; Accepted November 10, 2019

\begin{abstract}
Access to water in areas of high marginalization is undoubtedly one of the main problems to be solved. The objective of this study was to design two photovoltaic systems with solar pumps, the first to establish a planting area for vegetables, and the second with the purpose of bringing water for livestock consumption. The work was developed during the years 2015 and 2017 in the towns of Vicente Guerrero and Lázaro Cárdenas, municipalities of San Juan de Guadalupe Victoria, Durango, Mexico. In the first municipality there is a pond with a capacity of 50,000 cubic meters and in the second, there is a well. According to the maximum demands of crops $6.6 \mathrm{~mm} \mathrm{~d}-1$, a pump was designed with a capacity of $221.6 \mathrm{~m} 3 \mathrm{~d}-1$ and a total dynamic load of $25 \mathrm{~m}$ with 20 solar panels. In the second case, it consists of moving the water at a distance of 4.5 $\mathrm{km}$ and $62 \mathrm{~m}$ against the slope, for which a pump with a capacity of $30 \mathrm{~m} 3 \mathrm{~d}-1$ and a total dynamic load of $93.3 \mathrm{~m}$ was designed with eight solar panels.
\end{abstract}

\begin{abstract}
Resumen
El acceso al agua en zonas de alta marginación, es sin duda, uno de los principales problemas por resolver. El objetivo del presente estudio, fue diseñar dos sistemas fotovoltaicos con bombas solares, el primero para establecer una superficie de siembra de hortalizas, y el segundo con propósito de llevar agua para el consumo de ganado. Los trabajos se desarrollaron durante los años 2015 y 2017 en los pueblos de Vicente Guerrero y Lázaro Cárdenas, municipios de San Juan de Guadalupe Victoria, Durango, México. En el primer municipio se cuenta con un estanque de capacidad de 50000 metros cúbicos y en el segundo, se dispone de un pozo. De acuerdo a las demandas máximas de los cultivos $6.6 \mathrm{~mm} \mathrm{~d}^{-1}$, se diseñó una bomba con capacidad de $221.6 \mathrm{~m}^{3} \mathrm{~d}^{-1}$ y una carga total dinámica de $25 \mathrm{~m}$ con 20 paneles solares. En el segundo caso, consiste en trasladar el agua a una distancia de 4.5 $\mathrm{km}$ y $62 \mathrm{~m}$ contra pendiente, para lo cual se diseñó una bomba con capacidad de $30 \mathrm{~m}^{3} \mathrm{~d}^{-1}$ y una carga total dinámica de $93.3 \mathrm{~m}$ con ocho paneles solares.
\end{abstract}

Citation: MONTEMAYOR-TREJO, José Alfredo, WOO-REZA, José Luis, YESCAS-CORONADO, Pablo and FRIASRAMIREZ, Ernesto. Solar pumps: a sustainable alternative for agricultural systems in areas of high marginalization. JournalAgrarian and Natural Resource Economics. 2019 3-5: 1-7

\footnotetext{
* Correspondence to Author (email: jwoo_reza@hotmail.com)

$\dagger$ Researcher contributing as first author.
} 


\section{Introduction}

Addressing the negative effects caused to the environment by climate change, generated mainly by the indiscriminate use of fossil energy sources, is one of the main objectives that concern us today.

The generation and use of cleaner and more sustainable energy sources must be present in production systems. Photovoltaic energy is the process of directly converting energy from the sun into electricity, through the use of solar cells (Pérez and Maldonado, 2013). This, compared to the rest of renewable sources of energy, has among its most important advantages, the most accessible way of providing energy to billions of people without electricity in the world.

The production of photovoltaic energy, through the manufacture of solar panels, increased exponentially during the last fifteen years and it is expected that this trend will continue. Japan is the leading country, and Germany is at the forefront in the European Union. Both countries have based their growth on an adequate balance of research and development programs, associated with a successful fiscal policy that encourages the use of energy from renewable sources. (Hernández, 2007).

In Latin America, Brazil, Mexico and Chile have been the main countries with the highest investments in renewable energy, in which new investments in wind and solar energy stand out. In sectors that demand energy, the use of solar energy represents a great opportunity for reducing costs and carbon emissions into the atmosphere. The use of an emerging solar energy market in Mexico implies efforts to agree on national industrial development strategies and adoptions of new technologies (Ministry of Economy, 2017).

Currently, there are about 1.6 billion people who do not have access to electricity and the areas of the world with less access coincide with those regions of greatest poverty. The lack of electricity affects mainly the rural areas, where most of the people live in extreme poverty; $80 \%$ of people without access to electricity live in rural areas (Izquierdo and Eisman 2008; Sarmiento et al., 2017).
In Mexico, by 2010 the population was 112336538 inhabitants, of which 48090546 live in places of high to very high marginalization rate and two million inhabitants lack housing with electric power (CONAPO, 2010).

In these places, there are potential areas where new technologies can be incorporated to bolster better socio-economic development. Agriculture and livestock are common activities in rural areas. However, one of the main causes that limit their development is the lack of electricity.

In the state of Durango, Mexico, are located the communities of Vicente Guerrero (Siete Zacates) and Lázaro Cardenas (El Zacate). Both communities are considered with a high marginalization rate. In the former, a pond with a storage capacity of $50,000 \mathrm{~m}^{3}$ of water was built. Runoff caused by rainfall has sustained the volume of water in the pond greater than $50 \%$ of its capacity.

Therefore, the need to incorporate a surface to agriculture was raised, where vegetables and legumes can be grown, which would favor the diet of the inhabitants.

Given the lack of electricity, the objective was the incorporation of an area of six hectares for agriculture, with a photovoltaic pumping system and a high efficiency irrigation system in the application and distribution of water, such as the system of drip irrigation with belt.

The Zacate community presented the problem of supplying water for livestock consumption during the dry season.

Livestock feeds mainly of pastures in the upper parts (mountains) that border the Ejido. Livestock consists of bovines and goats, which, during dry season, must travel four to five kilometers to access the river water and, in extreme weather, the mortality due to water limitation can occur.

Here, the objective was to bring water from a well located on the banks of the river and store it in Australian-type ponds with a photovoltaic pumping system and a buried pipe system, with a distance of four and a half kilometers and a counterslope of $62 \mathrm{~m}$ high. 


\section{Methodology to develop}

\section{Site location for the Siete Zacates case study}

The community of Siete Zacates is located between the coordinates $102.62^{\circ}$ of East longitude and 24.54 of North latitude, the climate of the region according to the classification of Köpen modified by (García, 1973) is semi-arid dry (BSk) with annual rainfall of less than $600 \mathrm{~mm}$ and its average temperature is $19^{\circ} \mathrm{C}$.

Water is available from a pond or pot of water with a capacity of $50000 \mathrm{~m}^{3}$, it is fed by surface currents derived from upstream precipitation and converging.

The agricultural area to be established is six hectares, with the purpose of planting crops in the Spring-Summer and Autumn-Winter cycles. In a first stage, two hectares were established, and the crops of tomato, pepper, pumpkin, cucumber and melon were sown, these were transplanted during the Spring-Summer 2015 agricultural cycle. A cyclonic mesh was installed in the perimeter of the surface, with the objective of avoiding the introduction of rodents to avoid damage to the crop. The irrigation system used was drip irrigation with "belt", it consists of six irrigation sections, three-inch main pipe, filters and a venturi fertilizer injector. The irrigation tape was an expense of five liters per linear meter.

\section{Water demands of crops}

Water demands for the crops are related to the concept of evapotranspiration. This is an important element in order to estimate water demands and improve water productivity (López et al., 2015). Evapotranspiration is made up of water that evaporates from the soil surface and water that the plant transpires to carry out photosynthetic processes.

The concept of evapotranspiration of the reference crop (ETo) was introduced to study the demand for evapotranspiration of the atmosphere, regardless of the type and development of the crop, and management practices; to estimate this demand, the " $A$ " class evapoporimeter tank method (FAO Irrigation and Drainage Study 56, 1990) was used. The equation is expressed as:

$\mathrm{ET}=\mathrm{kp} \mathrm{Ev}$

ISSN 2524-2091

RINOE® All rights reserved
Where $(\mathrm{kp})$ is a coefficient of the tank, which depends on the conditions that surround it and (Ev) is the daily evaporation that occurs and is expressed in $\mathrm{mm} \mathrm{d}^{-1}$. For the design of the irrigation system, the term maximum evaporation $\left(\mathrm{ETo}_{\max }\right)$, also known as design evapotranspiration, was used; maximum evapotranspiration occurs during maximum crop development and generally takes place during the months with the highest solar incidence.

It is an essential indicator in the water balance available for irrigation programming (Prasanna, et al., 2008). The maximum daily volume $\left(\mathrm{V}_{\max }\right)$ was calculated as:

$$
\mathrm{V}_{\max }=\left[\left(\mathrm{ETo}_{\max } \mathrm{S}\right) / \mathrm{Ea}\right] \mathrm{F}
$$

Where (S) is the surface to be irrigated or incorporated into irrigation, (Ea) is the efficiency of water application, which depends on the method of irrigation to be used and $(\mathrm{F})$ is the fraction of the surface to be irrigated, which depends of the crop (Boswell, 1990). In the design of the project, a drip irrigation system was used, these systems have an application efficiency of $90 \%$.

\section{Calculation of peak solar hours and pump expense}

In a photovoltaic system, the pump operates according to peak solar hours (Thsp) which depends on the intensity of the incident radiation $\mathrm{kW}-\mathrm{h} \mathrm{m}^{-2} \mathrm{~d}^{-1}$ and divide it by the Standard Test Condition (STC) which is $1000 \mathrm{~kW}-\mathrm{h} \mathrm{m} \mathrm{m}^{-2} \mathrm{~d}^{-1}$ of radiation and cell temperature of $25^{\circ} \mathrm{C}$ (Solar Energy International, 2007). Thus, the pump's operating time or peak solar hours are determined by the equation:

Thsp $=$ Incident radiation $\mathrm{kW}-\mathrm{h} \mathrm{m}^{-2} \mathrm{~d}^{-1} / 1000 \mathrm{~kW}-\mathrm{hm}^{-2} \mathrm{~d}^{-1}$

The pump expense was calculated with the ratio:

$\mathrm{Q}=\mathrm{V}_{\max } / \mathrm{Thsp}$

\section{Total dynamic load of the pump}

The total dynamic load $(\mathrm{H})$ is the sum of friction losses $\left(\mathrm{h}_{\mathrm{f}}\right)$ plus the operating pressure of the irrigation system $\left(\mathrm{h}_{\mathrm{op}}\right)$ required by the last section of the irrigation system, that is, the section farthest from the pumping source. The operating pressure of the system is specified by the manufacturer of the irrigation system.

MONTEMAYOR-TREJO, José Alfredo, WOO-REZA, José Luis, YESCAS-CORONADO, Pablo and FRIAS-RAMIREZ, Ernesto. Solar pumps: a sustainable alternative for agricultural systems in areas of high marginalization. Journal-Agrarian and Natural Resource Economics. 2019 
$\mathrm{H}=\mathrm{hf}+\mathrm{h}_{\mathrm{op}}$

Friction losses were calculated using the Hazen Williams equation cited by (Vegas et al., 2018) and expressed as:

$$
\text { hf }=10.674 \mathrm{~L} \mathrm{D}^{-4.87}\left(\mathrm{Q}_{\mathrm{t}} / \mathrm{C}_{\mathrm{HW}}\right)^{1.852}
$$

Where: (L) is the length of the pipe in $\mathrm{m}$, (D) is the diameter of the pipe in $m,\left(Q_{t}\right)$ is the expense of the pipe in $\mathrm{m}^{3} \mathrm{sec}^{-1}$ and $\left(\mathrm{C}_{\mathrm{HW}}\right)$ is the Hazen Williams coefficient which depends on the type of material the pipe is made of. One of the reasons for using this formula is for mathematical simplicity and direct solution (Provenzano et al., 2007).

\section{Pump capacity and number of panels}

The capacity of the pump is determined by equation (7) where: $\left(B_{H P}\right)$ is the power of the pump in horsepower, $\mathrm{Q}$ is the expense $\left(\mathrm{m}^{3} \mathrm{sec}^{-}\right.$ $\left.{ }^{1}\right),(\gamma)$ is the specific weight of water $\mathrm{kgf} \mathrm{m}^{-3}$, total dynamic load $(\mathrm{m}),(\mathscr{E})$ is the efficiency of the pump and 75 is the conversion factor, i.e. a horsepower is equal to $75 \mathrm{kgf}-\mathrm{m} \mathrm{s}^{-1}$ (Moreno et al., 2018). A factor of 1.3 is recommended to apply to the power of the pump (Uzquiano et al., 2015). The horsepower of the pump was converted to watt, that is, a $\mathrm{B}_{\mathrm{HP}}$ is equal to 745.7 watt.

$$
\mathrm{B}_{\mathrm{HP}}=[(\mathrm{Q} \gamma \mathrm{H}) /(75 \mathscr{E})] 1.3
$$

The number of panels (NP) was calculated by dividing the power of the pump, by the power of a single panel $\left(\mathrm{P}_{\mathrm{p}}\right)$, multiplied by the efficiency $(\eta)$ of the panels. Its value ranges from 0.85 to 0.9 (Alonso, 2019).

$\mathrm{NP}=\mathrm{B}_{\mathrm{HP}} /\left(\mathrm{P}_{\mathrm{p}} \eta\right)$

\section{Location of the site for the case study El Zacate}

El Zacate is located between the coordinates $102.84^{\circ}$ of East longitude and 24.72 of North latitude, the climate of the region according to the classification of Köpen modified by (García, 1973 ) is semi-arid dry (BSk) with rainfall less than $600 \mathrm{~mm}$ annually and average temperature of $19^{\circ} \mathrm{C}$. The ejido is located next to the Agua Naval River, which channels the rainfall that occurs between the states of Zacatecas and Durango.
The source of water supply is a well or wheel with a depth of twelve meters. This is fed by water that is filtered from the river, and according to pumping tests performed, the well can sustain an expense of six $\mathrm{L} \mathrm{s}^{-1}$.

\section{Water demand for cattle}

Water demand for livestock consumption were previously consulted with the ejido authorities and local farmers. It was based on the fact that an adult bovine consumes water between 8 and $10 \%$ of its weight.

A dairy cow can consume between 38 and 110 liters of water per day, a beef cattle from 26 to $70 \mathrm{~L} \mathrm{~d}^{-1}$ and a sheep from 4 to $15 \mathrm{~L} \mathrm{~d}^{-1}$. Pregnant females consume more water and lactanting ones consume more than dry ones (Duarte, 2019). Thus, the daily volume $\left(\mathrm{V}_{\mathrm{d}}\right)$ was estimated with equation (9), where $(\mathrm{Nc})$ is the number of head of cattle and (CPP) is the average daily water consumption per capita.

$\mathrm{V}_{\mathrm{d}}=\mathrm{Nc}$ CPP

\section{Calculation of peak solar hours and pump expense}

The pumping time was calculated with equation (3) and the pump cost with equation (10), where $\mathrm{Vd}$ is the daily volume demanded by cattle, which depends on the number of heads and water consumption per capita.

$\mathrm{Q}=\mathrm{V}_{\mathrm{d}} / \mathrm{Thsp}$

\section{Total dynamic load}

The total dynamic load was obtained with equation (11), where $(\Delta \mathrm{Z})$ is the difference between the point where the water is to be pumped, to the point where it is to be carried. The negative sign means a slope in favor and the positive sign a slope against the circulation of water. Friction losses were calculated with equation (4)

$\mathrm{H}=\mathrm{hf} \pm \Delta \mathrm{Z}$

\section{Pump capacity and number of panels}

Pump capacity was estimated with equation (7) and the number of panels with equation (8).

\section{Results for the case study of Siete Zacates.}




\section{Water demands of crops}

Maximum evapotranspiration was estimated with equation (1); according to (Irrigation and Drainage Study FAO 56, 1990) the tank coefficient was 0.7 and studies carried out by (Montemayor et al., 2012) indicate that, for the climatic zone, there is a maximum evaporation average value of the tank of $9.5 \mathrm{~mm} \mathrm{~d}^{-1}$. Therefore, the Eto ${ }_{\max }$ calculated was $6.6 \mathrm{~mm} \mathrm{~d}^{-1}$. Eto $_{\max }=0.7 \times 9.5 \mathrm{~mm} \mathrm{~d}^{-1}=6.6 \mathrm{~mm} \mathrm{~d}^{-1}$

This value coincides with those reported by (Irrigation and Drainage Studies FAO 26, 1990; García, 1973) for climatic zones with extreme temperatures, greater than $30^{\circ} \mathrm{C}$. The maximum daily volume was obtained with equation (2). Thus, for an area of six hectares or $60,000 \mathrm{~m}^{2}$, the volume of $221.6 \mathrm{~m}^{3} \mathrm{~d}^{-1}$ was obtained.

$$
\begin{aligned}
& \mathrm{V}_{\max }=\left[\left(0.00665 \mathrm{~m} \mathrm{~d}^{-1} \quad 60000 \mathrm{~m}^{2}\right)\right. \\
& \text { /0.9) }] 0.5=221.6 \mathrm{~m}^{3} \mathrm{~d}^{-1} .
\end{aligned}
$$

This value of $221.6 \mathrm{~m}^{3} \mathrm{~d}^{-1}$, represents the maximum demand for water that can occur for a given day, usually it takes place when the crops are in maximum development and temperatures are at their highest.

\section{Calculation of peak solar hours and pump expense}

According to the location of the project with a longitude of $102.62^{\circ} \mathrm{N}$ and a latitude $24.72^{\circ} \mathrm{E}$, six to nine $\mathrm{kW}-\mathrm{h} \mathrm{m} \mathrm{d}^{-1}$ are received, with the months of April to October being the ones with the highest radiation (NASA Prediction of Worldwide Energy Resources, 2019).

The peak solar hours obtained according to equation (3) were six hours of minimum operation and nine hours of maximum operation of the photovoltaic system. To calculate the pump cost, the minimum operating time was considered. Thus, according to equation (4), the pump expense was:

$\mathrm{Q}=221.6 \mathrm{~m}^{3} / 6 \mathrm{~h}=36.93 \mathrm{~m}^{3} \mathrm{~h}^{-1}=0.01 \mathrm{~m}^{3} \mathrm{~s}^{-1}$.

\section{Total dynamic load of the pump}

The total dynamic load is the sum of friction losses and the operating pressure that the irrigation system requires.
In a belt irrigation system, a ten meter $h_{o p}$ water column (mca) is recommended by the manufacturer; friction losses were calculated with equation (6), the length of the pipe was 350 $\mathrm{m}$, which is the distance from the pump to the farthest irrigation section, the internal diameter of the pipe is $0.08 \mathrm{~m}$, the Pipeline expense is 0.01 $\mathrm{m}^{3} \mathrm{~s}^{-1}$ and $\mathrm{C}_{\mathrm{HW}}$ is 150 for polyvinyl chloride (PVC) pipes.

$\mathrm{h} f=10.674350 \mathrm{~m}(0.08 \mathrm{~m})^{-4.871}(0.01 / 150)^{1.852}$ $=15.14 \mathrm{mca}$

Thus, friction losses were 15.14 mca. The total dynamic load of the pump is given by equation (7) which gives us a total dynamic load of 25.14 mca.

$\mathrm{H}=10 \mathrm{mca}+15.14 \mathrm{mca}=25.14 \mathrm{mca}$.

\section{Pump capacity and number of panels}

With the total dynamic load and water demand by the system, the pump power is calculated using equation (5). $B_{\mathrm{HP}}=\left[\left(0.01 \mathrm{~m}^{3} \mathrm{~s}^{-1} 1000 \mathrm{~kg} \mathrm{~m}^{-}\right.\right.$ $\left.\left.{ }^{3} 25 \mathrm{~m}\right) /(750.75)\right] 1.3=5.7$ H.P $=4,250.4$ watt

Thus, for a total dynamic load of $25 \mathrm{mca}$ and an expense of $0.01 \mathrm{~m}^{3} \mathrm{sec}^{-1}$ considering a pump efficiency of 0.75 , we calculated for a pump motor power that resulted in $5.7 \mathrm{H}$. $\mathrm{P}$ and equal to 4250.4 watt.

\section{Number of panels}

The number of panels was calculated with equation (8), where: 20 panels

$\mathrm{NP}=\left[\begin{array}{l}4 \\ 250.4 \text { watt } /(250 \text { watt } 0.85)\end{array}\right]=$

The twenty panels were connected in series and oriented to the south, with an inclination angle of $25^{\circ}$; an inclination equivalent to latitude is recommended by (Palacios y Morales 2017). The panels were connected to an inverter with a capacity of five $\mathrm{kW}-\mathrm{h} \mathrm{m}^{2} \mathrm{~d}^{-1}$ and the AC outputs were connected to the pump.

\section{Results for the case study of EI Zacate.}

\section{Water demand for cattle}

The daily volume of water was calculated with equation (9), an average per capita consumption (CPP) of $50 \mathrm{~L} \mathrm{day}^{-1}$ was obtained.

MONTEMAYOR-TREJO, José Alfredo, WOO-REZA, José Luis, YESCAS-CORONADO, Pablo and FRIAS-RAMIREZ, Ernesto. Solar pumps: a sustainable alternative for agricultural systems in areas of high marginalization. Journal-Agrarian and Natural Resource Economics. 2019 
To size our daily demands, we considered a cattle herd of 600 heads. Thus, the daily volume was 36,000 liters per day.

$\mathrm{V}_{\mathrm{d}}=600 * 50 \mathrm{~L} \mathrm{~d}^{-1}=30,000 \mathrm{~L} \mathrm{~d}^{-1}=30 \mathrm{~m}^{3} \mathrm{~d}^{-1}$

\section{Calculation of peak solar hours and pump expense}

Peak solar hours or operating time of the photovoltaic system were calculated with equation (3). According to the location of the $102.84^{\circ}$ East longitude and 24.72 North latitude, were received at least $5.75 \mathrm{~kW}-\mathrm{h} \mathrm{m} \mathrm{m}^{-2} \mathrm{~d}^{-1}$ to 9 . $\mathrm{kW}-\mathrm{h} \mathrm{m} \mathrm{m}^{-2} \mathrm{~d}^{-1}$ (NASA Prediction of Worldwide Energy Resources, 2019 ). The above indicates that the system can operate from $5.75 \mathrm{hr}$ to 9.75 h. A minimum time of six was considered for the operation of the system. The pump expense was calculated with equation (6), where an expense of five $\mathrm{m}^{3} \mathrm{hr}^{-1}$ was obtained. Although, as mentioned above, the operating time of the pump can be up to nine hours. Therefore, the pumped volume can be much higher.

$\mathrm{Q}=30 \mathrm{~m}^{3} \mathrm{~d}^{-1} / 6 \mathrm{~h} \mathrm{~d}^{-1}=5 \mathrm{~m}^{3} \mathrm{~h}^{-1}$.

\section{Total dynamic load}

Friction losses were calculated with equation (7) with a pipe length of $4500 \mathrm{~m}$; the pipe diameter was two inches, the expense of $0.001 \mathrm{~m}^{3} \mathrm{sec}^{-1}$ and $\mathrm{C}_{\mathrm{HW}}$ of 140

$\mathrm{h} f=10.6744500 \mathrm{~m}(0.05 \mathrm{~m})^{-4.871}\left(0.001 \mathrm{~m}^{3} \mathrm{~s}^{-}\right.$ $1 / 140)^{1.852}=31.3 \mathrm{mca}$

The total dynamic load was calculated with equation (11), where the unevenness of the water mirror where the pumping source is located to the point where the Australian tanks were located was 62 meters. Thus, the total dynamic load was 93.3 mca.

$\mathrm{H}=31.3+62=93.3$ mca.

\section{Pump selection and number of panels}

The power of the pump was calculated with equation (5), for which an expense of $0.001 \mathrm{~m}^{3}$ $\mathrm{s}^{-1}$ and the total dynamic load of $93.3 \mathrm{mca}$ was considered.

$\mathrm{B}_{\mathrm{HP}}=\left[\left(0.001 \mathrm{~m}^{3} \mathrm{~s}^{-1} 1000 \mathrm{~kg} \mathrm{~m}^{-3} \quad 93.3 \mathrm{~m}\right) /(75\right.$

0.75)] $1.3=2.15$ H.P $=1603.2$ watt
The number of panels was calculated with equation (8), where the power of a single panel is 260 watt. Thus, we have:

$\mathrm{NP}=[1,603.2$ watt $/(260$ watt 0.85$)]=7.27$ panels

Eight panels were connected in series and oriented to the south with an inclination angle of $25^{\circ}$. The panels were connected to an inverter with a capacity of five $\mathrm{kW}-\mathrm{h} \mathrm{m} \mathrm{m}^{2} \mathrm{~d}^{-1}$ and subsequently the AC outputs were connected to the pump. The installed pump was with a maximum capacity of $5 \mathrm{~m}^{3} \mathrm{~h}^{-1}$ and a maximum load of 145 mca.

\section{Acknowledgments}

This project was funded by the Ministry of Agriculture, Livestock, Rural Development, Fisheries and Food of the State of Durango.

To C. Ing. María Elva Ortiz Pérez and to M.C Humberto Herrera Rodríguez for their unconditional support for the completion of the project.

\section{Conclusions}

In the case of Siete Zacates, the solar pump has worked normally and vegetables such as tomatoes, peppers, squash, garlic, onion and others have been produced. This has contributed to improve the diet of the residents of the community and the products are being marketed. In the case of the El Zacate study, there were no problems in the operation of the equipment and the effects of the dry season regarding animal mortality due to water limitations have been reduced.

\section{References}

Alonso, L. J. A. 2019. www.sfc-solar.com

Boswell, J. M. 1990. Microirrigation Design Manual. Fourth ed. Hardie Industries. El Cajon, CA. USA. 7-12.

Consejo Nacional de Población (CONAPO) 2010.

http://www.conapo.gob.mx/es/CONAPO/Indice s_de_Marginacion_2010_por_entidad_federativ a_y_municipio 
Duarte, E. 2019. Uso del agua en establecimientos agropecuarios (Part I). https://www.planagropecuario.org.uy/publicaci ones/revista/R_139_52.PDF.

Estudio FAO Riego y Drenaje 56. 1990. Evapotranspiración del cultivo. Guías para la determinación de los requerimientos de agua de los cultivos. 298 p. ISSN 0254-5293

García, E. 1973. Modificaciones al sistema de clasificación climática de Köppen. Instituto de Geografía. Universidad Nacional Autónoma de México (UNAM). Mexico, Mexico City. 217 p.

Hernández, G. L. M. 2007. Energía, energía fotovoltaica y celdas solares de alta eficiencia http://www.revista.unam.mx/vol.8/num12/art89 /int89.htm

Izquierdo, L. y Eisman, J. 2008. La electrificación sostenible de zonas rurales aisladas mediante microsistemas eléctricos renovables. XV Simposio Solar Peruano. Cajamarca (Peru)

López, A. J. E., Díaz, V. T.., Watts, T. C.., Rodríguez, J. C., Castellanos, V. A. E., Partida, R. L., Velázquez, A.T. de J. 2015. Evapotranspiración y coeficientes de cultivo de chile bell en el Valle de Culiacán, Mexico. Terra Latinoamericana, 33 (3), 209-219.

Montemayor, T. J. A., Lara, M. J. L., Woo, R. J. L., Munguía, L. J., Rivera, G. M. y Trucíos, C. R. 2012. Producción de maíz forrajero (Zea mays L.) en tres sistemas de irrigación en la Comarca Lagunera de Coahuila y Durango México. Agrociencia. 46(3):267-278.

Moreno, T. I.D., Martiliano, C.E., De la Rosa, A. A.A., Aguilera, C. Y. 2018. Parámetros de bomba centrífuga de doble succión para la industria azucarera. Revista Ciencias Técnicas Agropecuarias. 27(2): 1-11

NASA Prediction of Worldwide Energy Resources. 2019. https://www.power.larc.nasa.gov/

Palacios, R.J. I., Morales, B. A. 2017. Productividad de paneles solares monocristalinos. Memorias del XXIII Congreso Internacional Anual de la SOMIM. Cuernavaca Morelos, Mexico. ISSN 2448-5551
Pérez, G. E., Maldonado, R. J. L. 2013. Fuente alterna de energía renovable: Celdas solares orgánicas. Entreciencias: diálogos en la Sociedad del Conocimiento. 1(1): 19-29

Prasanna, H. G., Chavez, J.L., Colaizzi, P.D., Steve, R.E., Howell, T.A. and Tolk, J.A. 2008. ET mapping for agricultural water management: present status and challenges. Irrig. Sci. 26: 223237.

Provenzano, G., Palav-Salvador, G., Bralts, F.V. (2007). Discusion of "Modified Hazen-Williams and Darcy Weisbach Equations for Friction and Local Head Losses along Irrigation Laterals" by John D. Valiantzas. J. Irrig. Drain Eng. 133 (4):417-420.

Sarmiento, N. I., Cardebas, E.Y., Valencia, O.G. 2017. Análisis cienciométrico de la investigación de sistemas fotovoltaicos integrados a edificios desde el año 2000 a 2017. Revista Espacios. 38(47): 29

Secretaria de Economía. 2017. La Industria Solar Fotovoltaica y Fototérmica en México. ProMéxico. www.gob.mx promexico@promexico.gob.mx._Primera edición. Mexico City, ISBN: 978-607-97294-86

Solar Energy International (SEI). 2007. Fotovoltaica manual de diseño e instalación. Pérez, B. H. (Trad.). New Society Publishers. Gabriola Island, Canada. 325 p.

Uzquiano, C., Sullivan, M., Sandy, X. 2015. Capacitación e instalación de sistemas fotovoltaicos en las comunidades de Carmen del Emero y Yolosani. Primera edición. Wildlife Conservation Society (Eds) 